УДК 911.52:550.424 (477.85)

\title{
ECOLOGICAL-GEOCHEMICAL ESTIMATION OF THE ROAD GEOSYSTEMS IN THE PRUT-DNIESTER WATERSHED (WITHIN CERNIVTSI REGION)
}

\author{
Mykhailo Tanasyuk, Galina Hodan \\ Yuriy Fedkovych National University of Chernivtsi, \\ Kotsubinsky St., 2, UA - 58012 Chernivtsi, Ukraine
}

The study of general ecological peculiarities of road geosystems should be conducted on the basis of analysis and evaluation of geochemical showings. Among anthropogenic factors influencing the formation of ecological-geochemical peculiarities of road geosystems the means of transportation have a considerable negative impact as sources of contamination. That's why the study of ecological-geochemical condition of road geosystems all enables us to estimate them and to determine the change dynamics.

On the basis of the conducted researches of the Prut-Dniester watershed geosystems, the concentration coefficients are calculated, there being determined the showings of contamination intensivity of the natural component and the integral indicator of the ecological danger, there being given a general evaluation of the ecological-geochemical situation of the road geosystems of the investigated area.

Key words: road geosystems, technogenic contamination, ecological-geochemical composition, ecological-geochemical situation, ecological estimation.

Introduction. Landscape contamination due to the sources of technogenic influence leads to their transformation, i.e. change. Ecological problems solving, connected with technogenic geochemical influence on the environment is one of the main tasks of the majority of nature sciences. Evaluation of the area ecological condition requires the application of the ecologicalgeochemical methods of research particularly. As the most urgent task of the modern society is the improvement of the ecological conditions of the environment.

One of the main pointers of the ecological quality of the landscape complexes are the geochemical properties. Also the important moment while analyzing the ecological condition of the road geosystems of the investigated area, which influence all the spheres of the human activity as well as nature systems functioning.

Road geosystems are one of the most active varieties of the anthropogenic landscapes, their properties change continuously, and these changes depend on the technogenic loading and autotransportation contamination.

Road geosystems within Prut-Dniester watershed have been chosen as an object of the research, as a subject-ecological-geochemical peculiarities of an area. The purpose of the study is improvement of theoretical-methodological principles, means and methods of investigation of anthropogenic, particularly road geosystems.

(C) Tanasyuk M., Hodan G., 2014 
Task setting. The study of the general ecological peculiarities of road geosystems condition is impossible to carry out without analysis and evaluation of the geochemical showings of landscape components (soils, underground and surface waters, biomass etc).

The research of the ecological-geochemical peculiarities of the road geosystems allows to estimate the current ecological condition of the natural components, determine the dynamics of their changes and to outline the ways for further rational usage.

The analysis of the previous researches. The basic theoretical and methodical ground for study and research of anthropogenic and, in particular, road geosystems comprise scientific works of domestic owe and foreign scientists such as F. Milkov, A. Isachenko, P. Shyshchenko, V. Nikolaev, L. Voropai, V. Ghutsuliak, G. Shwebs, V. Pashchenko, M. Grodzynskiiiy, I. Kovalchuk, G. Denysyk etc.

Ecological-geochemical investigation of anthropogenic landscapes was carried out by M. Glazovska, Yu. Saet, I. Avessalomova, L. Shevchenko, V. Ghutsuliak, L. Malysheva, I. Voloshyn.

Summary of the main research results. Road geosystems of the Prut-Dniester watershed of Cernivtsi region belong to forest-steppe type of landscapes. They are characterized by both common and distinguishing ecological-geochemical peculiarities.

The common features of the area: loess-like loam soils of different mechanical composition; the expansion of meadow forests with small forest patches; the availability of a number of terraces in the river valleys; erosion relief forms (gorges, ravines, valleys); predominance of climatic conditions of the forest-steppe type (warm and mild wet). Some physical-geographical regions of the Prut-Dniester area have distinguishing features, e.g. karst relief forms, steep rock slopes in the Dniester valley, landslide processes, swamped areas on the dikes ets.

The group of lithomorphological components belongs to the natural factors of formation of geochemical and ecological landscapes peculiarities. This group makes for general geochemical characteristics of basic and parent rocks, soils (lithogenic basis). Lithologic differences of rocks are connected with abilities to accumulate contaminating substances and landscape sell purification. The overall orografical plan of the investigated area is rather complicated. Altitude discrepancies, different angles of surface bias create different ecological-geochemical peculiarities on a small area.

Great importance in the area ecological situation forming is played by surface and underground waters, their hydrological and hydrochemical peculiarities. For instance, alkali acid and oxidation renewing conditions of water promote the change of migration ability of different substances. A considerable differentiation of water content leads to dynamic deviations in the showings of macroelements contents in water and re-distribution of microelements.

Means of transportation have a crucial negative influence among anthropogenic factors of forming of ecological-geochemical peculiarities of landscapes. Their harmful exhaustis result in contamination of all natural landscape components and technogenic geochemical loading on landscape complexes.

Technogenic pressure of landscapes is reflected in accumulation of chemical elements in soils, plants, underground and surface waters and in the air of roadside ways. This happens both as a result of biological elementseizing and mechanical overtake of technogenesis products. Exhaust gases contain very harmful substances (lead compounds, nitrogen oxides, carbonates, carbon oxides) which accumulate near the ground and disperse slowly.

Technogenic contamination leads to landscape complexes changes and changes in landscape components geochemical peculiarities. It's possible to estimate these changes in quantity or to 
determine ecological condition of this or that landscape component by analysing geochemical coefficients. Various authors offered different methodical approaches to ecological condition estimation through coefficients but they all depend on the completeness of the analytical materials, which characterizes the degree of geochemical awareness of some area. The more analyses of soils, waters, air, vegetation we have, the more precisely we can evaluate the landscape ecological condition. Among showings of such estimation we can highlight clarks of concentration, coefficients of concentration, total showings of contamination ets.

In each landscape component one can find a great amound of different chemical elements a which are not harmful for a human up to certain concentrations. The average contents of a chemical elements in the earths crust (lithosphere) is called a clark. Bat in each region depending on geological structure, soils types, geographical zoning and other factors, there will be their own, characteristic only of this region, average contents of this or that element. This average contents is called a regional background. It may be more or less than a clark.

So, only the contents of chemical substances which exceed a clark and a background contents are abnormal, i.e. harmful for smooth development and functioning of an ecosystem. If the contents of this or that element exceeds limiting allowable concentrations (LAC) then this element is toxic, i.e. harmful for a human organizm.

Abnormal element contents is determined by a formula:

\section{$\mathrm{Ki}=\mathrm{Ci} / \mathrm{Cf}$}

where $\mathrm{Ci}$ - element contents in the investigated component of are landscape; $\mathrm{Cf}$ - its natural background.

Calculations of these quantitative showings enable us to make an overall estimation of the ecological-geochemical condition of landscape components, to determine the degree of ecological changes of the environment in connection with contamination, which are carried out on the 5 point system and according to the following criteria: 1 - favourable (contamination is absent); 2 - relatively favourable (contamination is allowable, substance contents exceeds a background one, but not more than LAC in all landscape components); 3 - relatively unfavourable (contamination is relatively dangerous, contents of chemical substances exceeds LAC in soils); 4- unfavourable (contamination is dangerous, excess of LAC in soils and air); 5 - very unfavourable (contamination is very dangerous, substance contents exceeds LAC in all environments - soils, air, water, biota).

To estimate an ecological condition of an area one should condsider such important things as the indicator of contamination intensivity of a natural component $(\mathrm{Pj})$ and the integral indicator of ecological safety (In) of a landscape in relative units.

The calculation formula is

$$
P j=\sum_{i=l}^{n} M i \cdot K c i, I n=\sum_{i=l}^{m} P j \cdot T j, \text { where }
$$

$\mathrm{Mi}$ - value of danger (toxichess) index in accordance with danger class; $\mathrm{n}$ - amount of chemical elements being considered; Kc - coefficient of concentration (C) of a chemical element (i); $\mathrm{Tj}$ - translocational indicator of harmfulness shown in relative units ( for soils -2 , air -3 , underground waters -4 , biomass - 5); $\mathrm{m}$ - quantity of components ( $\mathrm{j}$ ) of a landscape. Indicators $\mathrm{Pj}$ and In are considered main in the estimation of the ecological-geochemical condition of an area. 
On the basis of the microelements contents data in the soils of road geosystems of the PrutDniester inter-river basin, there being calculated concentration coefficients, there being determined the indicators of contamination intensivity of the natural component $(\mathrm{Pj})$ and the integral integral indicator of ecological safety (In) (tables $1 ; 2)$.

Tables 1

Coefficients of microelements concentration in soils of the road geosystems of the Prut-Dniester watershed

\begin{tabular}{|c|l|c|c|c|c|}
\hline № & \multicolumn{1}{|c|}{ Adress } & \multicolumn{1}{|c|}{$\mathrm{Pb}$} & $\mathrm{Cu}$ & $\mathrm{Zn}$ & $\mathrm{Cd}$ \\
\hline 1 & c. Chernivtsi-v.Magala round-way circular road & 1,05 & 0,71 & 0,89 & 0,22 \\
\hline 2 & v. Magala Novoselytsia district, detouring road & 0,93 & 0,53 & 0,70 & 0,20 \\
\hline 3 & v. Prypruttia, Novoselytsia district & 1,00 & 0,78 & 0,87 & 0,33 \\
\hline 4 & c. Novoselytsia (town park) & 1,06 & 1,30 & 0,68 & 0,14 \\
\hline 5 & $\begin{array}{l}\text { v. Vanchikivtsi Novoselytsia district, turning to v. } \\
\text { Cherlena }\end{array}$ & 0,37 & 0,74 & 0,84 & 0,28 \\
\hline 6 & v. Mamalyga, Novoselytsia district & 0,76 & 0,72 & 0,48 & 0,12 \\
\hline 7 & v. Strointsi, Novoselytsia district & 0,45 & 0,5 & 0,31 & 0,06 \\
\hline 8 & $\begin{array}{l}\text { Crossroads of v. Zarozhany-Stavchany, Khotyn } \\
\text { district }\end{array}$ & 1,20 & 0,71 & 0,35 & 0,12 \\
\hline 9 & Four taverns, Khotyn district & 0,8 & 0,55 & 0,30 & 0,17 \\
\hline 10 & t. Khotyn, detouring road & 1,81 & 0,50 & 0,34 & 0,12 \\
\hline 11 & v. Ataky, Khotyn district bridge across r.Dniester & 1,46 & 0,70 & 0,32 & 0,14 \\
\hline 12 & v. Krokva, Kelmentsi district & 1,02 & 0,58 & 0,65 & 0,31 \\
\hline 13 & v. Perkivtsi, Kelmentsi district & 1,51 & 0,42 & 0,43 & 0,09 \\
\hline 14 & settlement Kelmentsi & 1,20 & 0,55 & 0,30 & 0,07 \\
\hline 15 & $\begin{array}{l}\text { Crossroad of v. Babyn and v. Burding, Kelmentsi } \\
\text { district }\end{array}$ & 1,05 & 0,74 & 0,44 & 0,12 \\
\hline 16 & v. Ivankivtsi & 1,15 & 0,68 & 0,31 & 0,17 \\
\hline 17 & v. Vaskautsi & 0,90 & 0,70 & 0,30 & 0,12 \\
\hline 18 & v. Romankivtsi & 1,46 & 0,55 & 0,30 & 0,07 \\
\hline 19 & v. Kolobchyn Sokyriany district & 0,35 & 0,5 & 0,31 & 0,08 \\
\hline 20 & c. Sokyriany & 1,20 & 0,71 & 0,36 & 0,12 \\
\hline
\end{tabular}

Concerning the received ecological characteristics and indicator we can give an overall estimation of the ecology-geochemical situation of road geosystems of the Prut-Dniester area. Thus, according to ecological-geochemical indicators the investigated area belongs to a favourable one, i.e. there is no contamination. The category of contamination intensivity is allowable, the amount $-\mathrm{Pj}$ is less than 15 .

Such results according to the evaluating scale of ecological safety of landscape contamination indicate the minimal frequency of functional deviations.

Conclusions. Road geosystems have their own peculiarities such as landscape-ecological diversity, high dependence of geochemical characteristics on technogenic loading, and contamination by transport means in particular.

Main tasks of investigation and study of road geosystems are development and implementation of principles and methods of optimization of their geochemical qualities. It is reflected in the 
necessity to regulate society influence on the environment. So, its is crucial to develop such means of autotransport controlling which would locate as precisely as possible unfavourable situations and enable the development of nature conserving measures concerning the management of a road network in corresponding landscape complexes.

Tables 2

Showings of contamination intensivity of natural components $(\mathrm{Pj})$ and showings of ecological safety (In)

\begin{tabular}{|c|l|c|c|c|c|c|c|}
\hline № & \multicolumn{1}{|c|}{ Adress } & $\mathrm{Pb}$ & $\mathrm{Cu}$ & $\mathrm{Zn}$ & $\mathrm{Cd}$ & $\sum \mathrm{Pj} 2$ & $\sum \mathrm{Pj} 2 * \mathrm{Tj} 2$ \\
\hline 1 & $\begin{array}{l}\text { c. } \text { Chernivtsi-v.Magala round-way } \\
\text { circular road }\end{array}$ & 4,2 & 2,13 & 3,56 & 0,88 & 10,77 & 21,54 \\
\hline 2 & $\begin{array}{l}\text { v. Magala Novoselytsia district, } \\
\text { detouring road }\end{array}$ & 3,72 & 1,59 & 2,8 & 0,8 & 8,91 & 17,82 \\
\hline 3 & v. Prypruttia, Novoselytsia district & 4 & 2,34 & 3,48 & 1,32 & 11,14 & 22,28 \\
\hline 4 & c. Novoselytsia (town park) & 4,24 & 3,9 & 2,72 & 0,56 & 11,42 & 22,84 \\
\hline 5 & $\begin{array}{l}\text { v. Vanchikivtsi Novoselytsia dis- } \\
\text { trict, turning to v. Cherlena }\end{array}$ & 1,48 & 2,22 & 3,36 & 1,12 & 8,18 & 16,36 \\
\hline 6 & v. Mamalyga, Novoselytsia district & 3,04 & 2,16 & 1,92 & 0,48 & 7,6 & 15,2 \\
\hline 7 & v. Strointsi, Novoselytsia district & 1,8 & 1,5 & 1,24 & 0,24 & 4,78 & 9,56 \\
\hline 8 & $\begin{array}{l}\text { Crossroads of v.Zarozhany- } \\
\text { Stavchany, Khotyn district }\end{array}$ & 4,8 & 2,13 & 1,4 & 0,48 & 8,81 & 17,62 \\
\hline 9 & Four taverns, Khotyn district & 3,2 & 1,65 & 1,2 & 0,68 & 6,73 & 13,46 \\
\hline 10 & t. Khotyn, detouring road & 7,24 & 1,5 & 1,36 & 0,48 & 10,58 & 21,16 \\
\hline 11 & $\begin{array}{l}\text { v. Ataky, Khotyn district bridge } \\
\text { across r.Dniester }\end{array}$ & 5,84 & 2,1 & 1,28 & 0,56 & 9,78 & 19,56 \\
\hline 12 & v. Krokva, Kelmentsi district & 4,08 & 1,74 & 2,6 & 1,24 & 9,66 & 19,32 \\
\hline 13 & v. Perkivtsi, Kelmentsi district & 6,04 & 1,26 & 1,72 & 0,36 & 9,38 & 18,76 \\
\hline 14 & settlement Kelmentsi & 4,8 & 1,65 & 1,2 & 0,28 & 7,93 & 15,86 \\
\hline 15 & $\begin{array}{l}\text { Crossroad of v. Babyn and v. Burd- } \\
\text { ing, Kelmentsi district }\end{array}$ & 4,2 & 2,22 & 1,76 & 0,48 & 8,66 & 17,32 \\
\hline 16 & v. Ivankivtsi & 4,6 & 2,04 & 1,24 & 0,68 & 8,56 & 17,12 \\
\hline 17 & v. Vaskautsi & 3,6 & 2,1 & 1,2 & 0,48 & 7,38 & 14,76 \\
\hline 18 & v. Romankivtsi & 5,84 & 1,65 & 1,2 & 0,28 & 8,97 & 17,94 \\
\hline 19 & v. Kolobchyn Sokyriany district & 1,4 & 1,5 & 1,24 & 0,32 & 4,46 & 8,92 \\
\hline 20 & c. Sokyriany & 4,8 & 2,13 & 1,44 & 0,48 & 8,85 & 17,7 \\
\hline
\end{tabular}

To improve the condition of road geosystems there should be carried out:

- improvement of transport means and their technical condition;

- to increase the control over fuel quality;

- rational organization of transportation and traffic direction;

- limitation of contamination expansion;

- rational build-up of highways;

- maximal greening of areas at the roadside lanes. 


\title{
LITERATURE
}

1. Gutsuliak V. M. Landscape ecology / V. M. Gutsuliak. - Cernivtsi : Ruta, 2002. - 272 p.

2. Gutsuliak V. M. Landscape analysis of road geosystems of Chernivtsi region/ V. M. Gutsuliak, G. D. Hodan, M. V. Tanasyuk // Science visnyk of Cernivtsi University. A collection of scientific publication : Geography. - Cernivtsi : Cernivtsic National university, 2009. Vol. 460. - P. 65-68.

3. The nature of Chernivtsi region / [edited by K. I. Gerenchuk]. - Lviv : Vishcha school, 1978. $-160 \mathrm{p}$.

4. Hodan G. D. Content of heavy metals in soils of road geosystems of the Prut-Dniester watershed / G. D. Hodan // Science visnyk of Cernivtsi University. A collection of scientific publication : Geography. - Cernivtsi : Cernivtsic National university, 2010. - Vol. 483. P. 50-54.

5. Tanasyuk M. V. Landscape-ecological analyses of the Prut area (within Kitsman district of Cernivtsi region) / M. V. Tanasyuk // Science notes of Vinnytsia state pedagogical university named after Mykhailo Kotsiubynskyi. Geography. - Vinnytsia, 2009. - Vol. 18. - P. 131-138.

\section{ЕКОЛОГО-ГЕОХІМІЧНІ ОСОБЛИВОСТІ ДОРОЖНІХ ЛАНДШАФТІВ ПРУТ-ДНІСТЕРСЬКОГО МЕЖИРІЧЧЯ (В МЕЖАХ ЧЕРНІВЕЦЬКОЇ ОБЛАСТІ)}

\author{
Михайло Танасюк, Галина Ходан \\ Чернівецький національний університет імені Юрія Федьковича, \\ вул. Кочюбинського, 2, 58012 Чернівиі, Україна
}

\begin{abstract}
Вивчення загальних екологічних особливостей дорожніх ландшафтів необхідно здійснювати на основі аналізу та оцінення геохімічних показників. Серед антропогенних чинників, що впливають на формування еколого-геохімічних властивостей дорожніх геосистем значний негативний вплив мають транспортні засоби, як джерела забруднення. Тому дослідження еколого-геохімічного стану дорожніх геосистем дає змогу нам оцінити ïx, та визначити динаміку змін.

На основі проведених досліджень геосистем Прут-Дністерського межиріччя обчислені коефіцієнти концентрації, визначені показники інтенсивності забруднення природного компонента та інтегральний показник екологічної небезпеки, узагальнено еколого-геохімічну ситуацію дорожніх геосистем досліджуваної території.

Ключові слова: дорожні ландшафти, техногенне забруднення, еколого-геохімічний стан, еколого-геохімічна ситуація, екологічне оцінення.
\end{abstract}




\title{
ЭКОЛОГО-ГЕОХИМИЧЕСКИЕ ОСОБЕННОСТИ ДОРОЖНЫХ ЛАНДШАФТОВ ПРУТ-ДНЕСТРОВСКОГО МЕЖДУРЕЧЬЯ (В ПРЕДЕЛАХ ЧЕРНОВИЦКОЙ ОБЛАСТИ)
}

\author{
Михаил Танасюк, Галина Ходан \\ Черновиикий национальный университет имени Юрия Федьковича, \\ ул. Кочюбинского, 2, 58012 Черновиьь, Украина
}

Изучение общих экологических особенностей дорожных ландшафтов необходимо осуществлять на основании анализа и оценки геохимических показателей. Среди антропогенных факторов, влияющих на формирование эколого-геохимических свойств дорожных геосистем значительное негативное влияние оказывают транспортные средства, как источник загрязнения. Поэтому исследования эколого-геохимического состояния дорожных геосистем позволяет нам оценить их, и определить динамику изменений.

На основе проведенных исследований геосистем Прут-Днестровского междуречья вычисленны коэффициенты концентрации, определенны показатели интенсивности загрязнения природного компонента и интегральный показатель опасности, дана общая оценка эколого-геохимической ситуации дорожных геосистем исследуемой территории.

Ключевые слова: дорожные ландшафты, техногенное загрязнение, экологогеохимический состояние, эколого-геохимическая ситуация, экологическая оценка. 